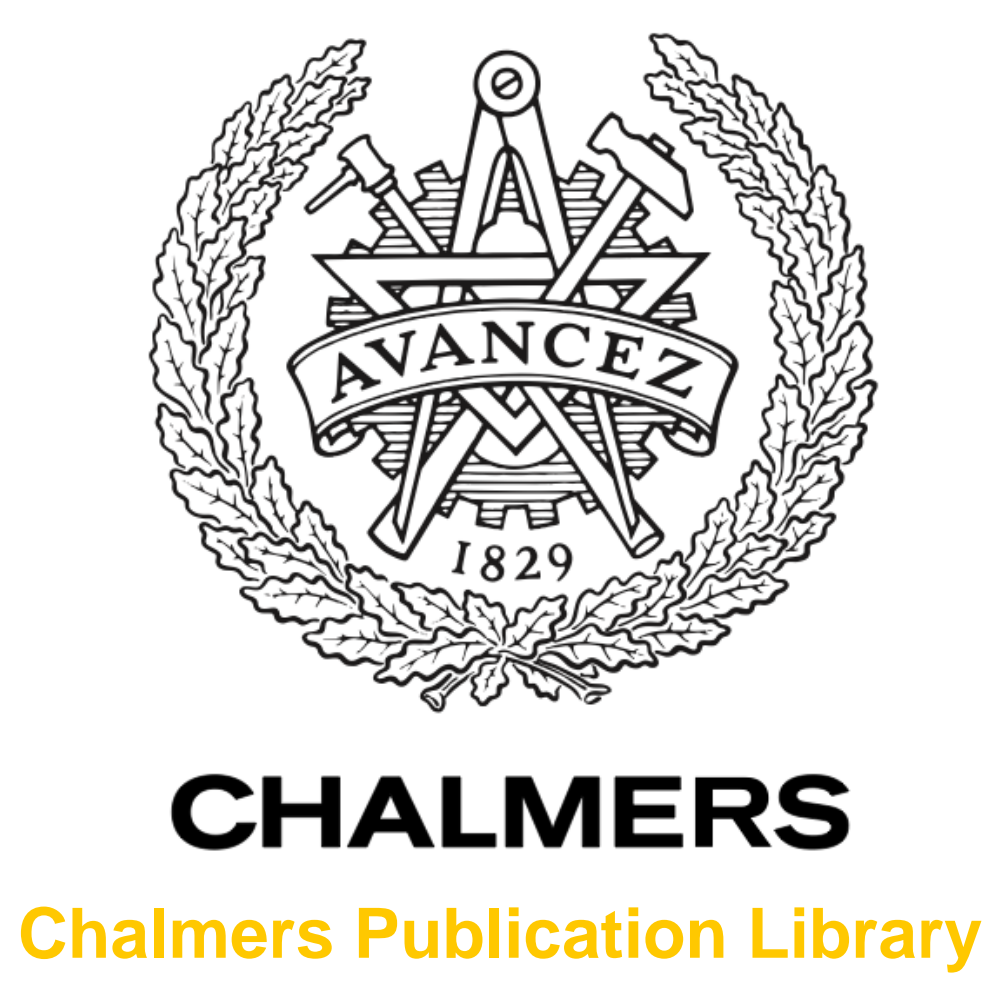

\title{
Reversed air staging - a method to reduce nitrous oxide emissions from circulating fluidized bed boilers
}

This document has been downloaded from Chalmers Publication Library $(\mathrm{CPL})$. It is the author's version of a work that was accepted for publication in:

Proceedings of the 7th International Workshop on Nitrous Oxide Emissions, Cologne, Ber. Bergische Univ. Gesamthochsch. Wuppertal Fachbereich 9 Phys. Chem.

Citation for the published paper:

Lyngfelt, A. ; Åmand, L. ; Müller, E. et al. (1997) "Reversed air staging - a method to reduce nitrous oxide emissions from circulating fluidized bed boilers". Proceedings of the 7th International Workshop on Nitrous Oxide Emissions, Cologne, Ber. Bergische Univ. Gesamthochsch. Wuppertal Fachbereich 9 Phys. Chem.(41), pp. 75-82.

Downloaded from: http://publications.lib.chalmers.se/publication/134920

Notice: Changes introduced as a result of publishing processes such as copy-editing and formatting may not be reflected in this document. For a definitive version of this work, please refer to the published source. Please note that access to the published version might require a subscription. 


\title{
REVERSED AIR STAGING - A METHOD TO REDUCE NITROUS OXIDE EMISSIONS FROM CIRCULATING FLUIDIZED BED BOILERS
}

\author{
by Anders Lyngfelt, Lars-Erik Åmand, Elke Müller* and Bo Leckner \\ Chalmers University of Technology, Göteborg, Sweden \\ *Presently at Lehrstuhl für Energieanlagentechnik, Ruhr-Universität, Bochum, Germany
}

\section{SUMMARY}

Reversed air staging is a method to reduce nitrous oxide $\left(\mathrm{N}_{2} \mathrm{O}\right)$ emissions from circulating fluidized bed boilers (FBBs). Tests in a $12 \mathrm{MW}$ circulating FBB show that the $\mathrm{N}_{2} \mathrm{O}$ emission can be lowered to one fourth without affecting the emissions of $\mathrm{NO}, \mathrm{SO}_{2}$ or $\mathrm{CO}$ and without adverse effects on the combustion efficiency. The focus of the paper is on the conditions in the combustion chamber. Measurements inside the combustion chamber reveal how the combustion conditions are affected by reversed air staging compared to normal air staging. These measurements confirm the working principle of reversed air staging, namely to provide more oxidizing conditions in the lower part of the combustion chamber and lower stoichiometry in the upper part of the combustion chamber.

\section{INTRODUCTION}

It is well known that the emissions of $\mathrm{NO}_{x}, \mathrm{SO}_{2}$ and $\mathrm{N}_{2} \mathrm{O}$ from coal combustion in fluidized bed boilers (FBBs) are significantly affected by changes in operational parameters like bed temperature and air supply. The problem is that a measure taken to decrease one of the emissions has the opposite effect on one or two of the others. The situation is illustrated in Fig. 1. Higher temperature leads to higher combustion efficiency and lower $\mathrm{N}_{2} \mathrm{O}$ emissions but higher $\mathrm{SO}_{2}$ and $\mathrm{NO}$ emissions, while a lower air ratio leads to lower $\mathrm{N}_{2} \mathrm{O}$ and NO emissions but higher $\mathrm{SO}_{2}$ emission and lower combustion efficiency. Fig. 1 highlights the conflict in the desire to reach low $\mathrm{N}_{2} \mathrm{O}$ and $\mathrm{SO}_{2}$ emissions and (wrongly) suggests that it is impossible to reduce $\mathrm{N}_{2} \mathrm{O}$ without increasing the $\mathrm{SO}_{2}$ emission.

The coupling of positive effects on $\mathrm{N}_{2} \mathrm{O}$ to negative effects on other pollutants can be circumvented by addressing the conditions in the upper and the lower parts of the combustion chamber separately. While the conditions in the upper part are important for the $\mathrm{N}_{2} \mathrm{O}$ emission, the effect of the conditions in the lower part is small or negligible. The sulphur capture, on the other hand, is greatly influenced by the conditions in the lower part. This difference in behaviour between $\mathrm{N}_{2} \mathrm{O}$ and $\mathrm{SO}_{2}$ is evident from studies of air staging, which affects the bottom part. ${ }^{1}$ Thus, a shift of conditions, providing more oxygen in the bottom 
part and less in the upper part, may reduce the $\mathrm{N}_{2} \mathrm{O}$ emission, while the sulphur capture remains unaffected. Such a reversal of the conditions compared to normal staging can be accomplished by so called reversed air staging $2,3,4$.

The results obtained with reversed air staging $2,3,4$ show, for instance, that it was possible to reduce the $\mathrm{N}_{2} \mathrm{O}$ emission to one fourth (from about 100 to $25 \mathrm{ppm}$ ), and NO to half (to 40 ppm) compared to normal air staging ${ }^{2}$, with a maintained sulphur capture efficiency of $90 \%$ but with increased $\mathrm{CO}$ emissions. However, in subsequent tests it was possible to attain the same decrease in $\mathrm{N}_{2} \mathrm{O}$ to one fourth, with the emissions of $\mathrm{SO}_{2}, \mathrm{NO}$ and $\mathrm{CO}$ unchanged compared to normal air staging 3,4 . This was accomplished by a reoptimization involving a somewhat increased air ratio and temperature in combination with increased limestone addition. The combustion efficiency (determined by loss of char with fly-ash) is not affected by reversed air staging except under conditions with very high $\mathrm{CO}$ emissions. ${ }^{4}$

In the present work the method is further studied by local measurements inside the combustion chamber with a zirconia-cell oxygen probe. The method has been used previously to characterize conditions in FBB combustion chambers ${ }^{5}$. The zirconia-cell oxygen probe can be used to determine whether the gas phase is over- or understoichiometric, and the purpose of the measurements is to investigate the conditions in the combustion chamber under reversed air staging and to compare them to those under normal air staging. An advantage with this probe compared to analysis of the extracted gas in conventional gas analysers is the high resolution in time. The conditions in a fluidized bed combustion chamber are characterized by rapid variations, and owing to the response time of conventional gas analysers, it would only be possible to determine whether the gas as an average is substoichiometric from the average gas concentrations measured. With a zirconia-cell oxygen probe it is possible to determine the fraction of time under substoichiometric conditions.

\section{EXPERIMENTAL CONDITIONS}

The 12 MW circulating FBB used has been described previously. ${ }^{1-5}$ The boiler is shown in Fig. 2. The height of the combustion chamber is $13.5 \mathrm{~m}$ and the square cross-section is about $2.5 \mathrm{~m}^{2}$. A feature of this boiler, of importance to the present tests, is the possibility to add air in the cyclone outlet and the uncooled exit chamber immediatly downstream of the cyclone outlet.

The sorbent was Ignaberga limestone and two similar bituminous coals (coal 1 and coal 2) with a medium sulphur content were used. Limestone and data for coal 1 have been presented previously. $2,3,4$

The equilibrium oxygen partial pressure is derived from the signal of the zirconia-cell. A typical signal shows rapid shifts between oxidising, i.e. more oxygen than combustible gases, and reducing conditions, i.e. less oxygen than combustible gases. Thus, the signal varies 
between approximately 0.03 and 0.85 volt, corresponding to an oxygen partial pressure of $10^{-}$ 1 to $10^{-16}$ bar. The signal is used to estimate the fraction of time under reducing conditions, $\mathrm{f}_{\text {red }}$, in the measured positions: $\mathrm{f}_{\text {red }}$ is the fraction of time during which the signal exceeds 0.4 $\mathrm{V}$. The sampling frequency was $20 \mathrm{~Hz}$ and the sampling period $300 \mathrm{~s}$.

During the oxygen probe measurements the boiler was run at a constant load with a total air-ratio of 1.2. The bed temperature was $850^{\circ} \mathrm{C}$, and the total pressure drop in the combustion chamber was $6 \mathrm{kPa}$. The limestone addition corresponded to a molar ratio of about 2.5-3. In the case of normal air staging, $60 \%$ of the combustion air was added through the bottom and $40 \%$ as secondary air in the front and back side at $2.2 \mathrm{~m}$ height. In the case of reversed air staging, approximately $85 \%$ of total air was added through the bottom, and the rest, 15\%, was added in the cyclone outlet. (There was no secondary air at $2.2 \mathrm{~m}$ in this case.)

For reversed air staging the fraction of air added in the cyclone outlet determines the combustor air ratio, $\lambda_{c}$, i.e. the air ratio in the combustion chamber before addition of final combustion air in the cyclone outlet. The combustor air ratio in the reversed air staging cases was about 1.03 for coal 1 and 1.05 for coal 2 and is an important parameter as will be seen below.

Fig. 3 shows the the cross-section of the combustion chamber and the nine measurement positions used. The letters indicate positions relative to the front wall, that is the wall where the fuel is added ( $\mathrm{f}$-front, $\mathrm{c}=$ centre, $\mathrm{b}=$ =back, $\mathrm{r}=$ right, $\mathrm{l}=\mathrm{left}$ ).

\section{RESULTS}

The oxygen probe measurements presented below were made in test series with the two bituminous coals. Coal 2 differs from coal 1 by yielding considerably lower $\mathrm{N}_{2} \mathrm{O}$ emissions, $60 \mathrm{ppm}$ instead of $100 \mathrm{ppm}$ for normal air staging at $850^{\circ} \mathrm{C}$. Emission results for coal 1 have been published previously for reversed air staging $2,3,4$, and an example from operation with coal 2 , is given in Fig. 4, which shows how the emissions depend on the combustor air ratio. A $90 \%$ reduction of $\mathrm{N}_{2} \mathrm{O}$ is obtained if $\mathrm{SO}_{2}$ and $\mathrm{CO}$ emissions are allowed to increase.

Fig. 5 shows how the fraction of time under reducing conditions, $f_{\text {red }}$, depends on the combustor air ratio, in position (cr) at $9.9 \mathrm{~m}$ height. A variation in the combustor air ratio in a rather narrow range shifts the conditions from almost entirely reducing to almost entirely oxidising and explains the strong dependence of emissions on the combustor air ratio shown in Fig. 4.

Figs. 6 and 7 show the distribution over the horizontal cross-section at $9.9 \mathrm{~m}$ height during normal and reversed air staging. In the normal staging case the fraction of time under reducing conditions is very small, whereas in the reversed air staging case $f_{\text {red }}$ varies between $18 \%$ and $95 \%$ with an average of about $60 \%$. This seemingly large variation over the cross- 
section should be considered in the light of the small change in air ratio needed to produce a shift between oxidizing and reducing conditions as shown in Fig. 5. These measurements were repeated with coal 2 yielding similar results, Fig. 8 and 9.

Similar measurements in the lower part at $1.5 \mathrm{~m}$ height reveal that reducing conditions clearly dominate in the normal air staging case, Fig. 10, while oxidizing conditions are predominant in the reversed air staging case, Fig. 11. A measurement during reversed air staging at $5.35 \mathrm{~m}$ height, Fig. 12, is slightly more reducing than the result obtained at $1.5 \mathrm{~m}$.

Fig. 13 shows a comparison between reversed and normal air staging for coal 1 versus height, measured in the centre position (cc) of the combustion chamber cross-section. In addition, the averages of the cross-section measurements $\left(\mathrm{x}_{\mathrm{ave}}\right)$ are included as well as data from previous measurements ${ }^{5}$ with a low-sulphur bituminous coal (coal 3) under normal air staging. Fig. 14 shows averages of cross-section measurements and measurements made in positions (cc) and (cr) at different heights for coal 2 . The results are similar to those obtained with coal 1: normal air staging is associated with reducing conditions in the bottom part and oxidizing conditions in the upper part, whereas reversed air staging is characterized by a moderate increase of the fraction of time under reducing conditions with height, i.e. a trend opposite to that of normal air staging. Thus, it is shown that reversed air staging actually reverses the situation in the combustion chamber, having an $f_{\text {red }}$ which increases with height. A comparison of the two cases of air supply clearly shows that with reversed air staging the fraction of time under reducing conditions can be significantly lowered in the lower part at the same time as it is substantially raised in the upper part.

\section{DISCUSSION}

The zirconia-cell measurements in the upper part during reversed air staging, Figs. 7 and 9, indicate that reducing conditions dominate there and, in addition, char combustion in the cyclone further lowers the gas stoichiometry. This may at first appear strange since the combustor is operated at a slight excess of air. However, even if the time fraction of reducing conditions is considerably larger than $50 \%$, the gas as a whole, if it were well mixed, could still be oxidising. (This possibility becomes obvious if one, for instance, assumes that the gas has a high oxygen content under oxidising conditions, and that the concentration of combustible gases is low under reducing conditions .)

The present results are related to a boiler with a $13.5 \mathrm{~m}$ high combustion chamber. Translation of the results to combustors with other sizes has not yet been treated. 


\section{CONCLUSIONS}

The following conclusions can be drawn from the oxygen probe measurements:

- With normal air staging the conditions are reducing most of the time in the bottom part and oxidizing most of the time in the upper part.

- With reversed air staging the difference between the upper and the lower part is more moderate. However, the data indicate an increase in the fraction of time under reducing conditions with height, i.e. a trend which is opposite to that of normal air staging.

- A comparison of normal air staging and reversed air staging indicates that reversed air staging results in more oxidizing conditions in the bottom part and more reducing conditions in the upper part. Thus, the results confirm the proposed working principle for reversed air staging.

- The fraction of time under reducing conditions in the upper part of the combustion chamber is very sensitive to small changes in the combustor air ratio. This also explains why the emissions are very sensitive to small changes in the combustor air ratio.

\section{ACKNOWLEDGEMENTS}

This work has received financial support from the Swedish National Board for Industrial and Technical Development (NUTEK).

\section{REFERENCES}

${ }^{1}$ Lyngfelt, A., and Leckner, B., "SO $\mathrm{S}_{2}$ Capture and $\mathrm{N}_{2} \mathrm{O}$ Reduction in a Circulating Fluidized-Bed Boiler: Influence of Temperature and Air Staging," Fuel 72 (1993) 1553-1559.

${ }^{2}$ Lyngfelt, A., Åmand, L.-E., and Leckner, B., "Low $\mathrm{N}_{2} \mathrm{O}$, NO and $\mathrm{SO}_{2}$ Emissions from Circulating Fluidized Bed Boilers," Proc. Int. Conf. Fluid. Bed Combustion 13 (1995) 10491057.

${ }^{3}$ Lyngfelt, A., Åmand, L.-E., and Leckner, B., "Methods for Reducing the Emission of Nitrous Oxide from Fluidized Bed Combustion," Energy Convers. Mgmt. 37 (1996) 1297 1302 .

${ }^{4}$ Lyngfelt, A., Åmand, L.-E., Karlsson, M., and Leckner, B., "Reduction of $\mathrm{N}_{2} \mathrm{O}$ Emissions from Fludised Bed Combustion by Reversed Air Staging," Institute of Energy's 2nd International Conference on Combustion and Emissions Control, London, 3-5 Dec. 1995, pp. 89-100.

${ }^{5}$ Lyngfelt, A., Bergqvist, K., Johnsson, F., and Leckner, B., "Dependence of Sulphur Capture Performance on Air Staging in a 12 MW Circulating Fluidised Bed Boiler," appearing in Gas Cleaning at High Temperatures, Eds. R. Clift and J.P.K.Seville, Blackie Academic \& Professional, Glasgow 1993, pp. 470-491, ISBN 0754101781. 


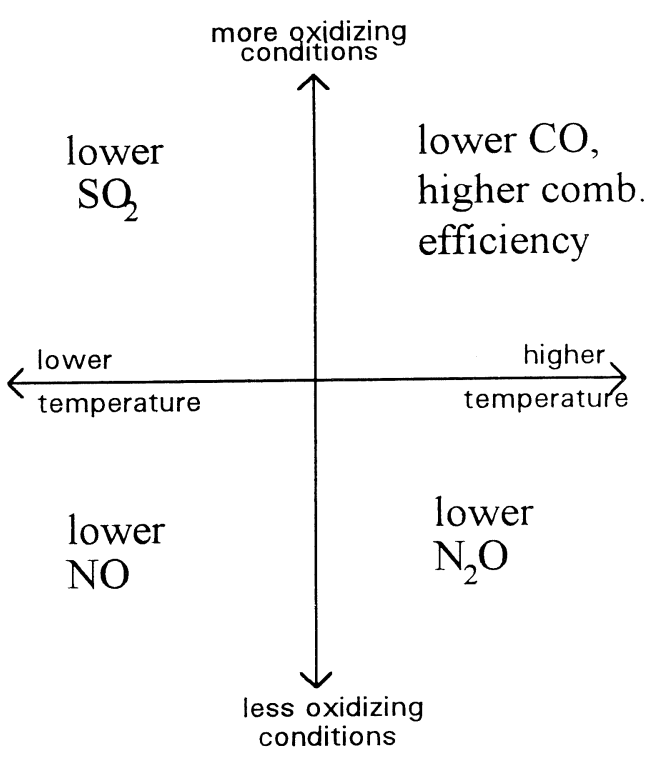

Fig. 1. Effect of changing temperature and air ratio (oxidizing/reducing conditions).

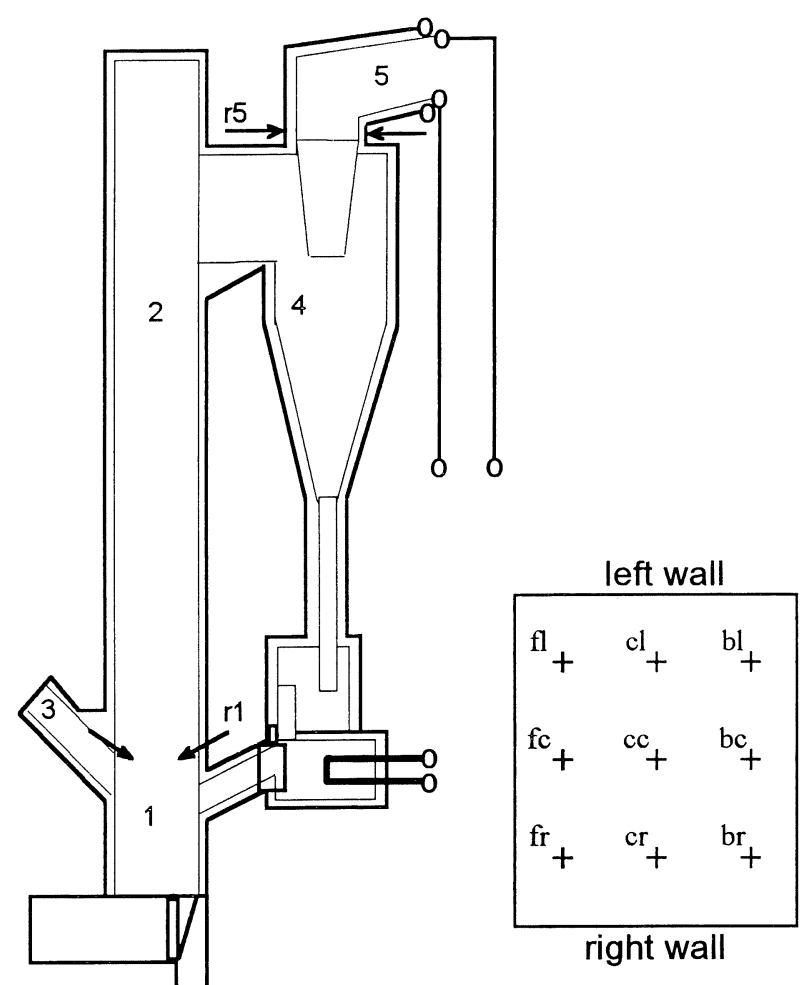

Fig. 2. Chalmers

Fig. 3. Cross-section $12 \mathrm{MW}$ boiler. measurement positions.

Combustion chamber: lower part (1), upper part (2); fuel feed (3); cyclone (4); exit duct (5); $\rightarrow$, secondary air nozzle inlets:

$\mathrm{r} 1$ at $2.2 \mathrm{~m}$ and $\mathrm{r} 5$ in cyclone outlet.

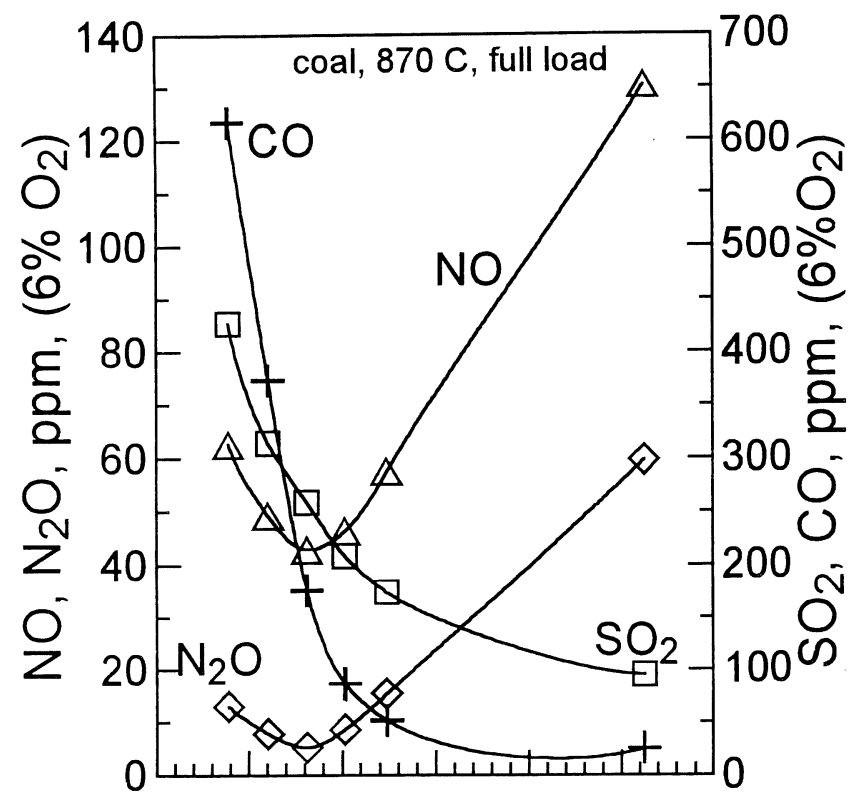

0.951 .001 .051 .101 .151 .201 .25 Combustor air ratio

Fig. 4. Emissions vs combustor air ratio for reversed air staging. Coal $2,870^{\circ} \mathrm{C}$. For comparison the emissions during normal air staging at $850^{\circ} \mathrm{C}$ are: $\mathrm{N}_{2} \mathrm{O}: 60 \mathrm{ppm}, \mathrm{NO}: 90$ ppm, $\mathrm{CO}: 50$ ppm and $\mathrm{SO}_{2}: 160-200 \mathrm{ppm}$.

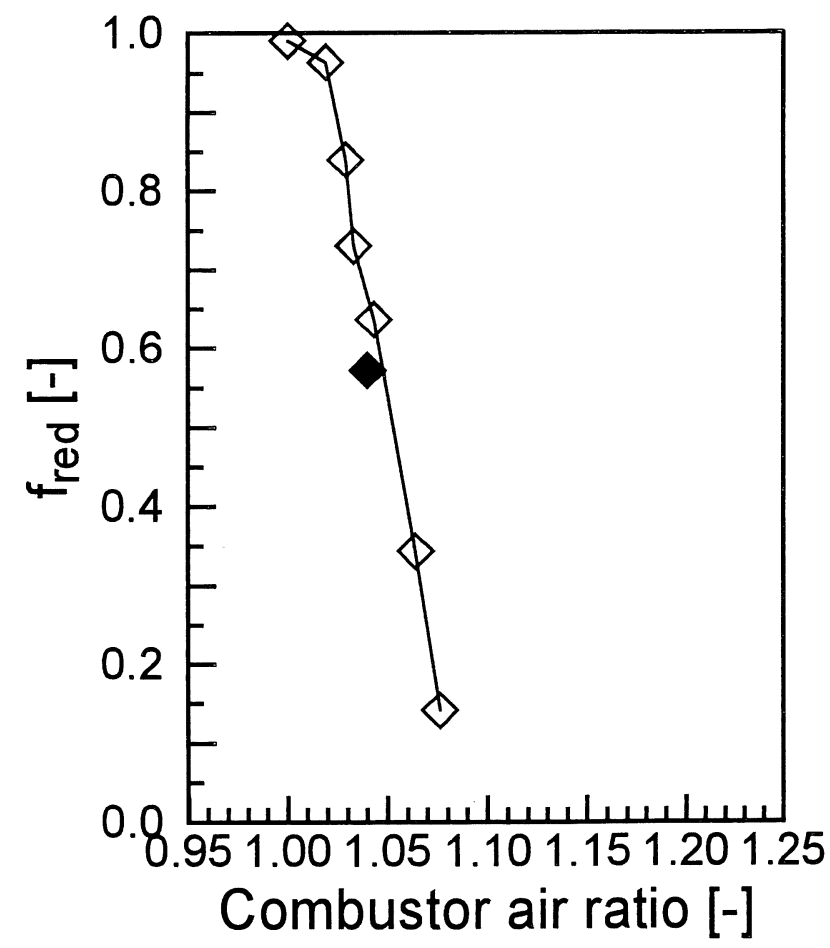

Fig. 5. $f_{\text {red }}$ versus combustor air ratio. Coal 1, position cr at $9.9 \mathrm{~m}$. (A measurement taken two days earlier illustrates reproducibility, 


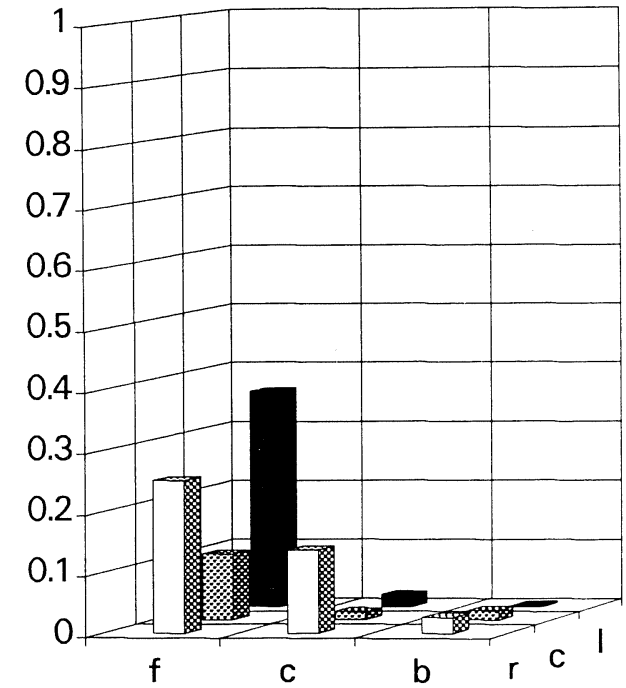

Fig. 6. $\mathrm{f}_{\text {red }}$ for normal air staging in the plane at $9.9 \mathrm{~m}$ height. Coal 1 .

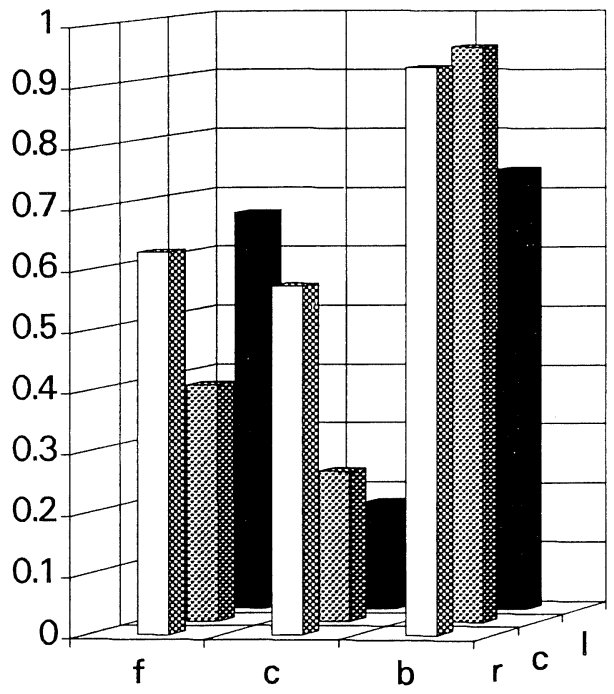

Fig. 7. $f_{\text {red }}$ for reversed air staging in the plane at $9.9 \mathrm{~m}$ height. Coal 1.

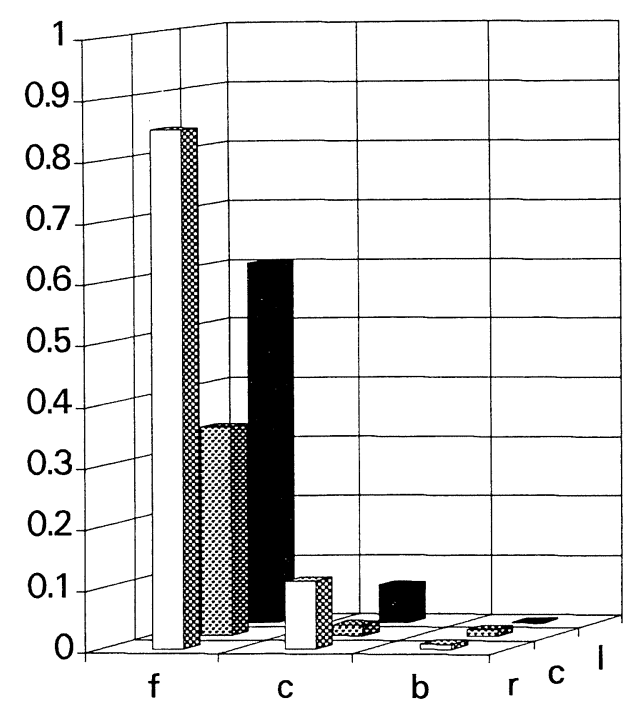

Fig. 8. $f_{\text {red }}$ for normal air staging in the plane at $9.9 \mathrm{~m}$ height. Coal 2.

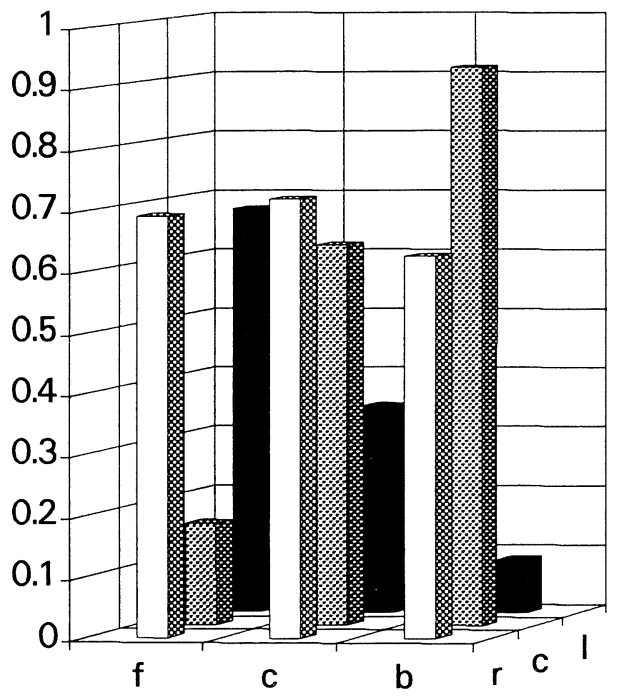

Fig. 9. $f_{\text {red }}$ for reversed air staging in the plane at $9.9 \mathrm{~m}$ height. Coal 2. 


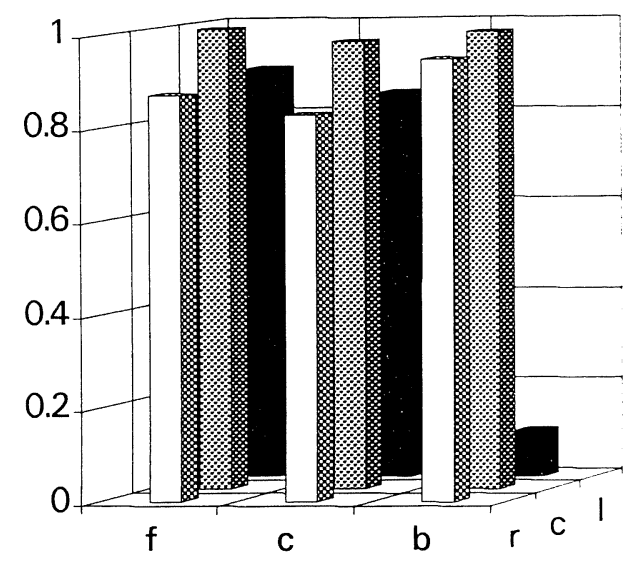

Fig. 10. $f_{\text {red }}$ for normal air staging in the plane at $1.5 \mathrm{~m}$ height. Coal 2.

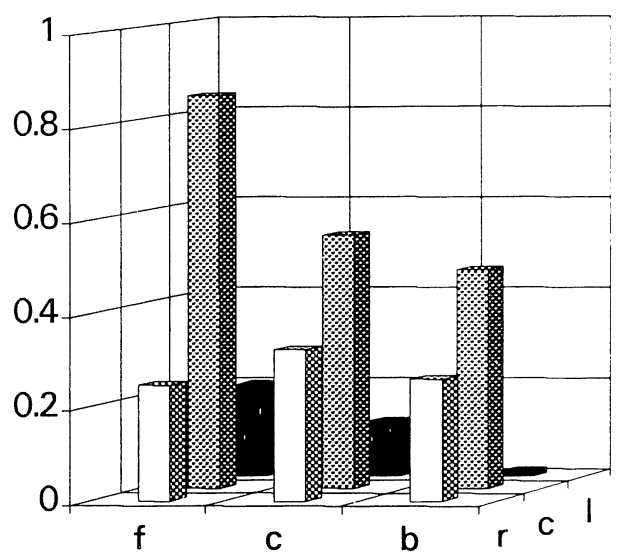

Fig. 11. $\mathrm{f}_{\text {red }}$ for reversed air staging in the plane at $1.5 \mathrm{~m}$ height. Coal 2.

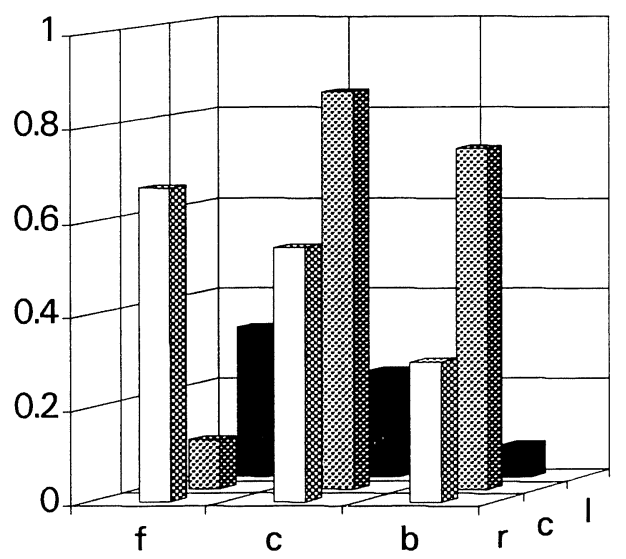

Fig. 12. $\mathrm{f}_{\text {red }}$ for reversed air staging in the plane at $5.35 \mathrm{~m}$ height. Coal 2.

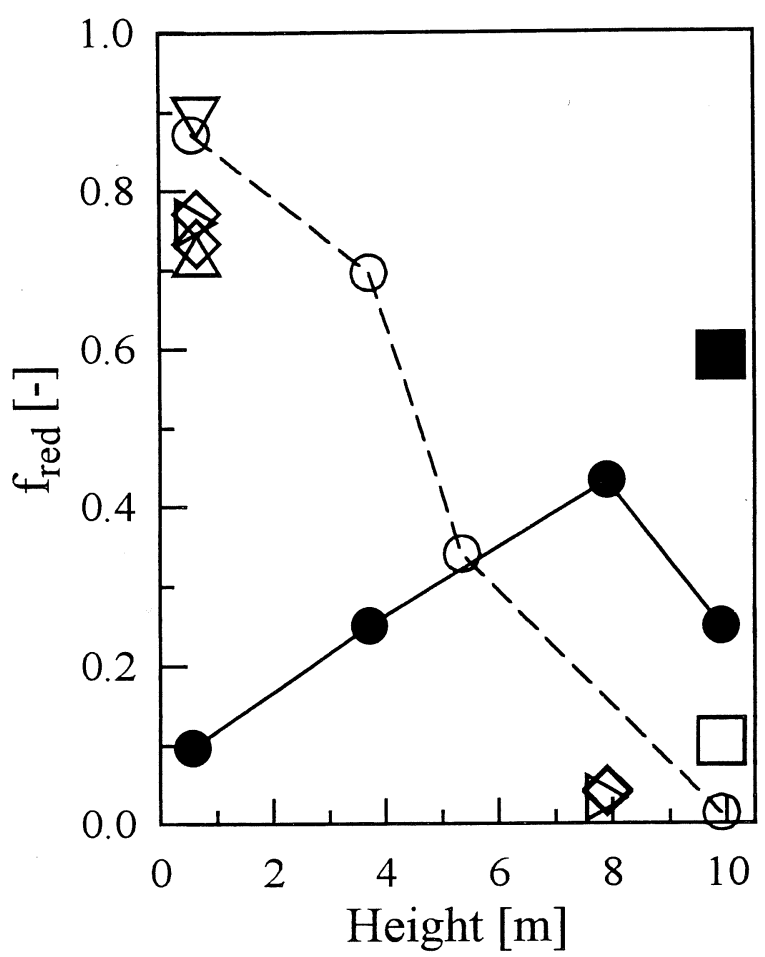

Fig. 13. $f_{\text {red }}$ vs height.

Reversed air staging, coal 1 (cc: $\bullet, \mathrm{x}_{\mathrm{ave}}: \square$ ).

Normal staging (open symbols):

coal 1, no limestone (cc: $O$, $x_{\text {ave }}: \square$ );

coal 3 (data from ${ }^{5}$ ) with limestone (cc: $\diamond$ :, cr $\triangleright)$ and dolomite (cc: $\Delta, \mathrm{cr}: \nabla)$.

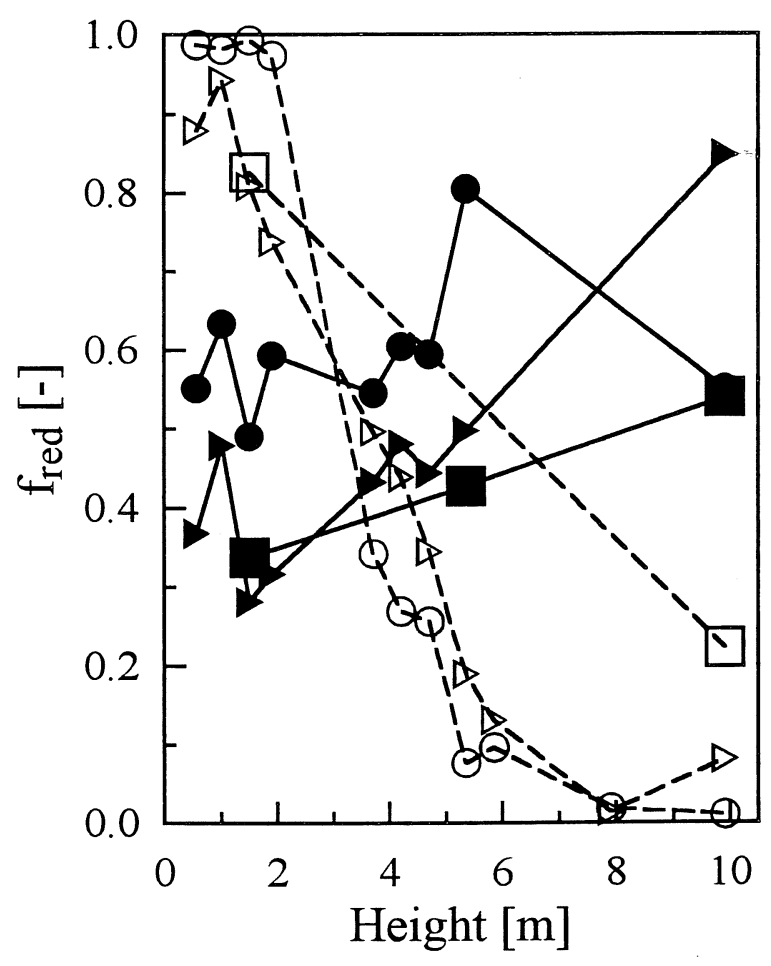

Fig. 14. $f_{\text {red }}$ vs height for coal 2. Reversed air staging: filled symbols and continuous lines; Normal air staging: open symbols and discontinuous lines. Cross-section averages $(\square$ $\square)$; position cc $(\mathrm{O}, \mathbf{O})$; position cr $(\triangleright, \triangleright)$. 